\title{
Purification and Characterization of Thermostable Cellulase Free Xylanase from Pseudomonas sp. XPB-6
}

\author{
Pawan Kumar Sharma, Duni Chand \\ Department of Biotechnology, Himachal Pradesh University, Shimla, India \\ Email: \{dcdbthpusml, pawan09hpubiotech\}@gmail.com
}

Received January 6, 2011; revised January 25, 2012; accepted February 5, 2012

\begin{abstract}
Extracellular cellulase free xylanase from Pseudomonas sp. XPB-6 was purified to homogeneity with 2.15 fold of purity and $60.31 \%$ yield, respectively by ammonium sulfate precipitation and DEAE ion exchange chromatography. The protein was found to be a homotrimer consisting of three subunits of $41 \mathrm{kDa}$ each and the native molecular weight of $123 \mathrm{kDa}$. The $\mathrm{pH}$ and temperature optimum for enzyme were 7.5 in $100 \mathrm{mM}$ sodium phosphate buffer at $60^{\circ} \mathrm{C}$ and was stable to a high and broader range of $\mathrm{pH}$ and to a temperature up to $75^{\circ} \mathrm{C}$. Kinetic experiments at $60^{\circ} \mathrm{C}$ gave $V_{\max }$ and $K_{\mathrm{m}}$ values of $144.92 \mathrm{U} / \mathrm{mg}$ and $0.60 \mathrm{mg} \cdot \mathrm{ml}^{-1}$ respectively for birch wood xylan. The enzyme had no apparent requirement for cofactors, and its activity was strongly inhibited $1 \mathrm{mM} \mathrm{Hg}^{2+}$ and $\mathrm{Cu}^{2+}$ while it was slightly inactivated by $1 \mathrm{mM}$ $\mathrm{Mg}^{2+}$ and $\mathrm{Pb}^{2+}$. Shelf life of xylanase of Pseudomonas sp. XPB-6 was studied both at room temperature and $4^{\circ} \mathrm{C}$. The enzyme was stable both at room temperature and at $4^{\circ} \mathrm{C}$ for 90 and 28 days respectively. The half-life of the enzyme was approximately 40 days at room temperature.
\end{abstract}

Keywords: Xylanase; Pseudomonas sp. XPB-6; Purification; DEAE Chromatography

\section{Introduction}

Enzymatic hydrolysis of plant cell walls plays a major role in the carbon cycle and is of increasing environmental and industrial significance. Enzymes which catalyze such process include xylanases, a $\beta$-1,4-xylose polymer that is decorated with various sugars. Xylanases efficiently hydrolyze unsubstituted xylans but these are unable to access highly decorated forms of the polysaccharide, such as arabinoxylans that contain arabinofuranose groups [1]. The xylanases are genetically single chain glycoproteins, usually $6-80 \mathrm{kDa}$ and active at temperature between $40^{\circ} \mathrm{C}$ and $60^{\circ} \mathrm{C}$ [2]. Xylanases effectively hydrolyze xylan, the principal type of hemicellulose containing a linear polymer of $\beta$-D-xylopyranosyl units linked by (1-4) glycoside bonds which act cooperatively to convert xylan to its constituent simple sugars. These enzymes include $\beta$-1,4-endoxylanases (xylanases; EC 3.2.1.8), which cleave internal glycosidic bonds within the xylan backbone; arabinofuranosidase (EC 3.2.1.55), which hydrolyzes arabinose side chains; R-glucuronidase (EC 3.2.1.131), which removes glucuronic acid side chains from xylose units; xylan esterases (EC 3.1.1.6), which release acetate groups and finally xylosidase (EC 3.2.1.37), which hydrolyzes xylobiose to xylose [3]. There is a considerable degree of synergy among these enzymes. Many xylanases do not cleave glycosidic bonds between xylose units that are substituted. Thus, side chains must be cleaved before the xylan backbone is completely hydrolyzed. Conversely, several accessory enzymes will only remove side chains from xylooligosaccharides and therefore require xylanases to partially hydrolyze the plant structural polysaccharide, before side chains can be cleaved $[3,4]$. These enzymes have ability to biodegrade lignocellulosic biomass to fuels and chemicals, improving rumen digestion and prebleaching of kraft pulp, mainly because of a desire to get rid of chlorine as a bleaching agent [5]. Xylanases have wide industrial applications, either alone or in association with other enzymes, in various processes such as pretreatment of forage crops and lignocellulosics biomass, improvement of nutrient utilization of cereal-based diets in pig and poultry, flour improvement for bakery products, saccharification of agricultural, industrial and municipal wastes, bleaching of cellulose pulps while decreasing consumption of chlorine containing chemicals and as an alternative to treatment with sulphuric acid of the textile-cellulosic waste [6-8]. Use of abundantly available agro-residues in fermentation processes serves the dual purpose of cost effective enzyme production and environment security [9]. Xylanases are produced by diverse genera and species of bacteria, actinomycetes and fungi. While several Bacillus species secrete high levels of 
extracellular xylanase, filamentous fungi secrete high amounts of extracellular proteins where xylanase secretion often accompanies cellulolytic enzymes for example as in species of Trichoderma, Penicillium, and Aspergillus [10].

\section{Microorganism}

In the present study a xylan metabolizing bacterium XPB-6 was isolated earlier in the Department of Biotechnology, Himachal Pradesh University, Shimla from the soil samples of Mandi (Himachal Pradesh, INDIA) has been explored for its xylanolytic activity. This bacterium has been identified as Pseudomonas sp. XPB-6 at Microbial Type Culture Collection (MTCC), Institute of Microbial Technology, Chandigarh (INDIA).

\subsection{Chemicals}

All the chemicals were of analytical grade. Media components were from HiMedia (Mumbai) and the inorganic salts were of analytical grades. The electrophoresis and molecular biology grade chemicals were used for protein purification.

\subsection{Quantitative Determination of Xylanolytic Activity}

A loopful of bacterial cells were inoculated in seed medium containing peptone $0.5 \%$, yeast extract $0.2 \%$, beef extract $0.2 \%$, dextrose $0.25 \%$ and was incubated at $30^{\circ} \mathrm{C}$ for 24 hours at $160 \mathrm{rpm}$. The precultures were added to $50 \mathrm{ml}$ production medium containing $0.5 \%$ peptone, $0.2 \%$ yeast extract, $0.2 \%$ beef extract and $0.25 \%$ xylan and were incubated at $30^{\circ} \mathrm{C}$ for 24 hours at $160 \mathrm{rpm}$. The culture contents were centrifuged at $10,000 \mathrm{~g}$ for $20 \mathrm{~min}$, at $0^{\circ} \mathrm{C}-4^{\circ} \mathrm{C}$ and supernatant thus collected was further assayed for xylanase activity as per the standard protocol mentioned below.

\subsubsection{Assay of Xylanase Activity}

Xylanase activity was assayed using birchwood xylan $0.5 \%$ as substrate and the amount of reducing sugar released was determined by DNSA (Dinitrosalicylic acid) method given by Miller, 1959 [11].

$\begin{array}{lc}\text { DNSA reagent comprised of following constituents } \\ \text { Dinitrosalicylic acid (DNS) } & 1 \% \\ \text { Sodium sulphite } & 0.05 \% \\ \text { Sodium Potassium Tartarate } & 20 \% \\ \text { Sodium Hydroxide } & 1 \% \\ \text { Phenol } & 0.2 \% \\ \text { Reaction mixture includes } & \\ \text { Xylan }(0.5 \%) & 100 \mu \mathrm{l} \\ \text { Phosphate buffer (50 mM, pH 7.0) } & 890 \mu \mathrm{l}\end{array}$

Enzyme

$10 \mu \mathrm{l}$

\section{Procedure}

Reaction mixture was incubated at $50^{\circ} \mathrm{C}$ for $10 \mathrm{~min}$ utes in water bath and then $3.0 \mathrm{ml}$ of dinitrosalicylic acid reagent (DNSA) was added to the mixture in the test tube to terminate the reaction. The test tubes were incubated in boiling water bath for 20 minutes to develop maximum colour and then cooled to room temperature and absorbance was recorded against blank at $540 \mathrm{~nm}$.

\section{Standard curve}

Calibration curve was prepared with D-xylose (20 $200 \mu \mathrm{g} / \mathrm{ml})$.

\section{Enzyme activity}

One unit of xylanase activity was expressed as the amount of enzyme required to produce $1 \mu \mathrm{mol}$ of reducing sugar (xylose equivalent) in 1 minute.

\subsubsection{Assay of Cellulase Activity}

Cellulase activity was determined as per procedure given in section 2.2 .1 by replacing xylan with cellulose (cotton linter, filter paper and $\mathrm{CMC}$ ).

\section{Purification of Cellulase Free Xylanase from Pseudomonas sp. XPB-6}

\subsection{Ammonium Sulphate Precipitation}

The crude enzyme was concentrated with ammonium sulphate precipitation as given by Scopes [12]. $100 \mathrm{ml}$ of crude enzyme was taken and ammonium sulphate was added in increasing saturation from $10 \%$ to $100 \%(\mathrm{w} / \mathrm{v})$. It was added with continuous stirring and stored at $4{ }^{\circ} \mathrm{C}$ for one hour. The precipitated proteins were recovered by centrifugation at 20,000 g for $30 \mathrm{~min}$. and suspended in $0.1 \mathrm{M}$ sodium phosphate buffer ( $\mathrm{pH}$ 7.5). Protein concentration and enzyme activity were estimated in each protein sample. The enzyme assay was carried out as described earlier in the Section 2.2.1. The optimum xylanase activity at a specific concentration of ammonium sulphate reflects the best concentration to attain maximum enzyme recovery.

\subsection{Dialysis}

After precipitation, the ammonium sulphate present in the enzyme solution was removed by subjecting the solution to dialysis in a buffer of $\mathrm{pH} 7.5$ at $4^{\circ} \mathrm{C}$ for 24 hours as described by Carmona et al. [13].

\subsection{Anion Exchange Chromatography}

The anion exchange chromatography was done with DEAE-cellulose column (9X, $20 \mathrm{~cm}$, bed volume $25 \mathrm{ml}$ ). The column packed with the matrix was washed in following sequence: 


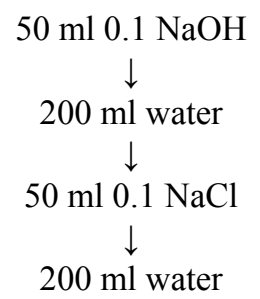

Further the column was equilibrated with $100 \mathrm{ml}$ of start buffer (0.1 M Sodium phosphate buffer, $\mathrm{pH}$ 7.5). The dialized enzyme sample was loaded on to the column, washed with $50 \mathrm{ml}$ of start buffer. Elution was done at flow rate of $0.5 \mathrm{ml} / \mathrm{min}$ initially with start buffer (sodium phosphate) $\mathrm{pH} 7.5,(50 \mathrm{ml})$, then sequentially with sodium phosphate buffer $\mathrm{pH} 7.5$ of four different ionic strength, prepared by adding $\mathrm{NaCl}$ of different molarity (0.3 M, 0.5 M, 0.7 M and 1.0 M). 10 fractions of all the four different concentrations were collected $(4 \mathrm{ml}$ fraction volume) and enzyme assay was performed in fractions that contained proteins as earlier described in Section 2.2.1. The protein fraction rich in xylanase activity were pooled and processed further.

\subsection{Protein Quantification}

The concentration of protein in the collected fractions was estimated by dye binding methodas givenby Bradford [14].

\subsection{Polyacrylamide Gel Electrophoresis (PAGE)}

The polyacrylamide gel electrophoresis was performed to analyze the molecular weight of the protein and purity of the fractions obtained from liquid ion exchange chromatography (Laemmli [15], Blackshear [16], Bollag and Edelstein [17]).

\subsubsection{Documentation of Gel}

The images of gel were recorded in a gel documentation system (Alpha Innotech Corporation, USA). The molecular weight analysis was done using Alpha Digi Doc RT and Alpha Ease FC software.

\subsubsection{Zymogram Analysis}

Xylanase activity in the polyacrylamide gel was examined using a zymogram staining technique. After Native-PAGE, the gel was sliced into two parts, one of which was subjected to the staining and destaining procedures mentioned above and the other part was washed twice with distilled water and then was incubated at $55^{\circ} \mathrm{C}$, $(0.5 \%)$ xylan $(100 \mu \mathrm{l}), 900 \mu \mathrm{l}$ sodium phosphate buffer $(0.1 \mathrm{M})$ for 5 minutes, then added DNSA $3 \mathrm{ml}$ and kept in a water bath for 10 minutes. The activity was observed as band turned brownish black.

\subsection{Characterization of Purified Xylanase}

The biochemical characterization of the purified Pseu- domonas sp. XPB-6 was performed to compare its properties with that of the other reported xylanases. The biochemical properties (molecular weight, $\mathrm{pH}$ and temperature optima, buffer molarity, thermal stability, $K_{\mathrm{m}}$ and $V_{\max }$ ) were investigated for the purified enzyme.

\subsection{Determination of Molecular Mass}

The molecular weight of the purified cellulase free xylanase from Pseudomonas sp. XPB-6 was determined by SDS/Native-PAGE.

\section{Results and Discussion}

The results of the experiments performed in this study are presented and discussed in the following sections.

\subsection{Purification of Cellulase Free Xylanase from Pseudomonas sp.}

\subsubsection{Ammonium Sulphate Precipitation}

Precipitation through ammonium sulphate was observed at $10 \%-100 \%$ and a cut of $60 \%-80 \%$ has been use for the further studies as the maximum activity $(31.3 \mathrm{U} / \mathrm{mg})$ was observed at $80 \%$ saturation. Carmona et al. [13], described that when different steps of purification were carried out, the total protein contents decreased with each step while the specific activity increased. They recorded the specific activity in the crude xylanase extract as $33.79 \mathrm{IU} / \mathrm{mg}$ that is found in conformity with the present case i.e. $31.3 \mathrm{IU} / \mathrm{mg}$ (Figure 1).

\subsubsection{Determination of Molecular Weight}

The ammonium sulfate precipitated enzyme ( $4 \mathrm{mg}$, sample volume $2 \mathrm{ml}$ ) was loaded on to the DEAE cellulose column after dialysis (MWCO $20 \mathrm{kDa}$ ) and the 34, 35, 36 and 37 active fractions were pooled and checked for purity by SDS PAGE (Figure 2). The detailed activity profile, yield and fold purification are tabulated. Complete purification was achieved by this strategy. The obtained active fractions were checked for purity with SDS PAGE method. The detailed activity profile, yield and fold purification are given in Table 1. The purity of the enzyme is complete, which can be seen in SDS PAGE gel where single band (41 kDa) appeared (Plate 1).

\subsection{Zymogram Analysis}

Xylanase activity in the polyacrylamide gel was examined using a zymogram staining technique. After Native-PAGE, the gel has shown a single band of $123 \mathrm{kDa}$ (trimer) turned black brown when subjected to enzyme assay conditions confirming the xylanase activity (Plate 2).

Menon et al., [18] reported $39 \mathrm{kDa}$ xylanase on SDS-PAGE. The zymogram analysis also revealed a single band of xylanolytic activity corresponding to the band 
obtained in SDS-PAGE. An unusual cell-associated $\beta$-1,4xylanase was purified to gel electrophoretic homogeneity from a cell extract of the bacterium Thermoanaerobacterium sp. strain JW/SL-YS485. The molecular mass of the xylanase was $350 \mathrm{kDa}$ as determined by gel filtration and $234 \mathrm{kDa}$ as determined by native gradient gel electrophoresis. Heterosubunits of 180 and $24 \mathrm{kDa}$ were observed for the xylanase on sodium dodecyl sulfate-polyacrylamide gradient gel electrophoresis [19].

\subsection{Characterization of Purified Xylanase}

\subsubsection{Optimization of Buffer System for Xylanase Assay}

Enzyme activity is much dependent on $\mathrm{pH}$. Different

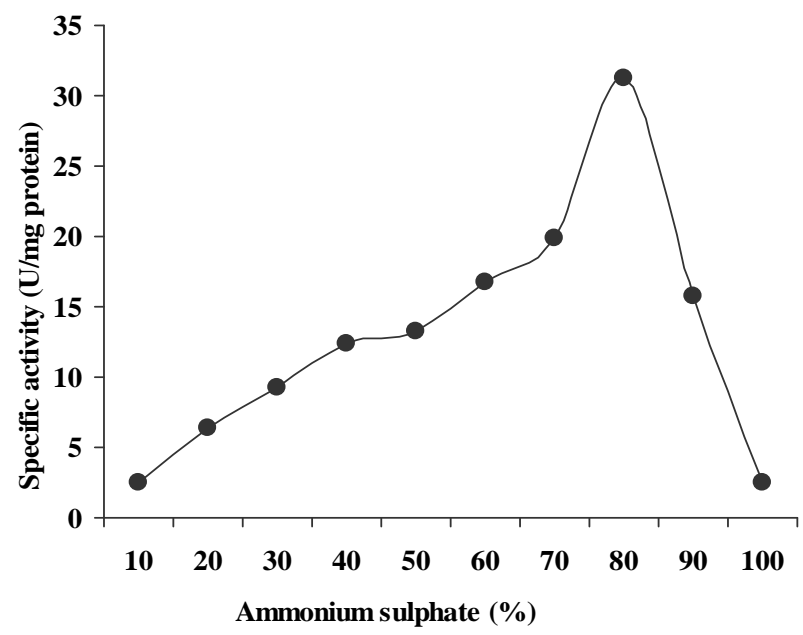

Figure 1. Precipitation through ammonium sulphate.

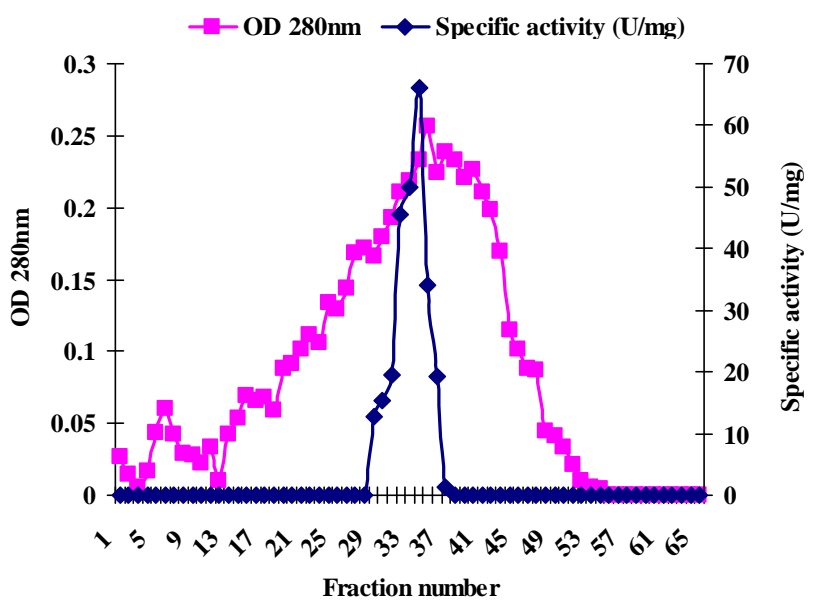

Figure 2. Purification profile.

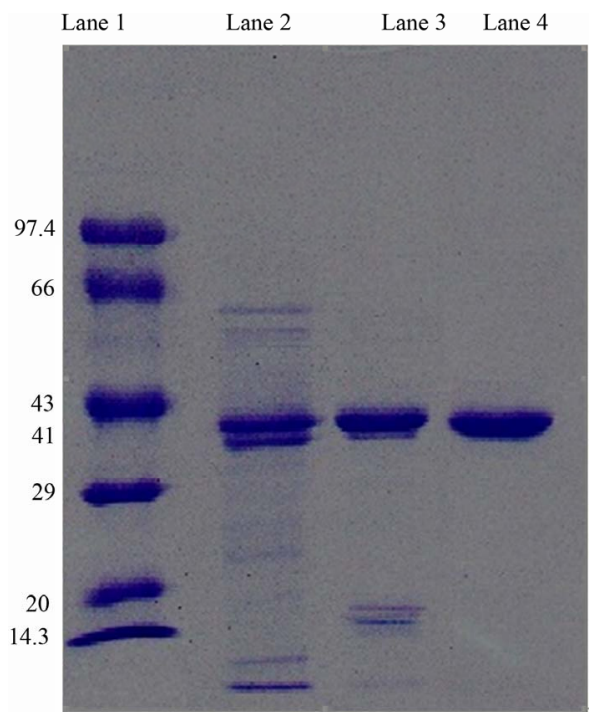

Lane 1: Molecular Weight Markers; Lane 2: Crude protein; Lane 3: Dialysed sample of ammonium sulphate precipitates; Lane 4: Pooled fractions of DEAE.

Plate1. SDS PAGE analysis for xylanase from Pseudomonas sp. XPB-6.

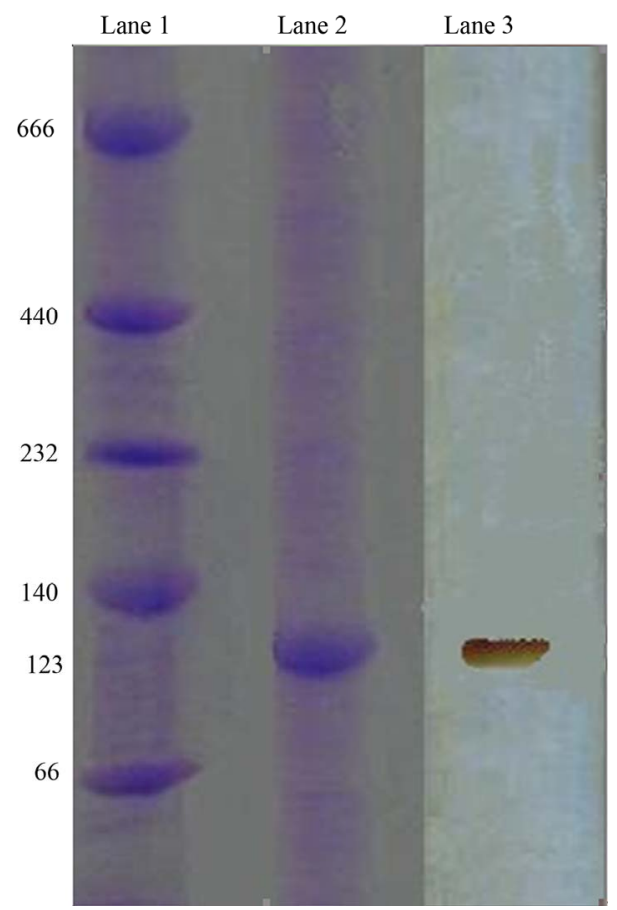

Lane 1: Molecular Weight Markers; Lane 2: Pooled fractions of DEAE; Lane 3: Zymogram showing enzyme activity.

Plate 2. Zymogram analysis by NATIVE PAGE for xylanase from Pseudomonas sp. XPB-6.

Table 1. Purification of xylanase.

\begin{tabular}{ccccccc}
\hline Purrification step & Volume of sample (ml) & Total activity & Total protein (mg) & Specific activity & Fold purification & Yield (\%) \\
\hline Crude & 50 & 731.25 & 39 & 18.75 & 1 & 100 \\
$\left(\mathbf{N H}_{\mathbf{4}} \mathbf{S}_{\mathbf{2}} \mathrm{SO}_{\mathbf{4}}\right.$ & 8 & 496.19 & 15.99 & 31.01 & 1.65 & 67.82 \\
DEAE-cellulose & 12 & 299.17 & 4.48 & 66.78 & 2.15 & 60.31 \\
\hline
\end{tabular}


buffers were used at $100 \mathrm{mM}$ concentration at various $\mathrm{pH}$ values. Among various buffers, sodium phosphate buffer at $7.5 \mathrm{pH}$ gave maximum activity (Figure 3 ). The results are close to that obtained from thermostable xylanase from Bacillus circulans [20]. Sanghi et al., [21] observed $\mathrm{pH}$ stability of the purified xylanase from Bacillus subtilis ASH. The purified enzyme was pre-incubated with citrate $(\mathrm{pH} 4.0$ - 6.0), phosphate $(\mathrm{pH} 6.0$ - 8.0) and Tris- $\mathrm{HCl}(\mathrm{pH} 8.0$ - 9.0) buffers for $10 \mathrm{~min}$ at room temperature followed by measurement of xylanase activity using sodium phosphate buffer $(0.05 \mathrm{M}, \mathrm{pH}$ 7.0). Maximum $\mathrm{pH}$ stability of the purified xylanase from $B$. subtilis ASH was between pH 6.0 - 7.5.

\subsubsection{Buffer Molarity}

To investigate the effect of different molar concentrations of phosphate buffer, the xylanase was arranged in $25 \mathrm{mM}$ to $200 \mathrm{mM}$ of sodium phosphate buffer at $\mathrm{pH}$ 7.5. Maximum xylanase activity was recorded in $100 \mathrm{mM}$ sodium phosphate buffer at $\mathrm{pH} 7.0$ (Figure 4). Sanghi et al.,

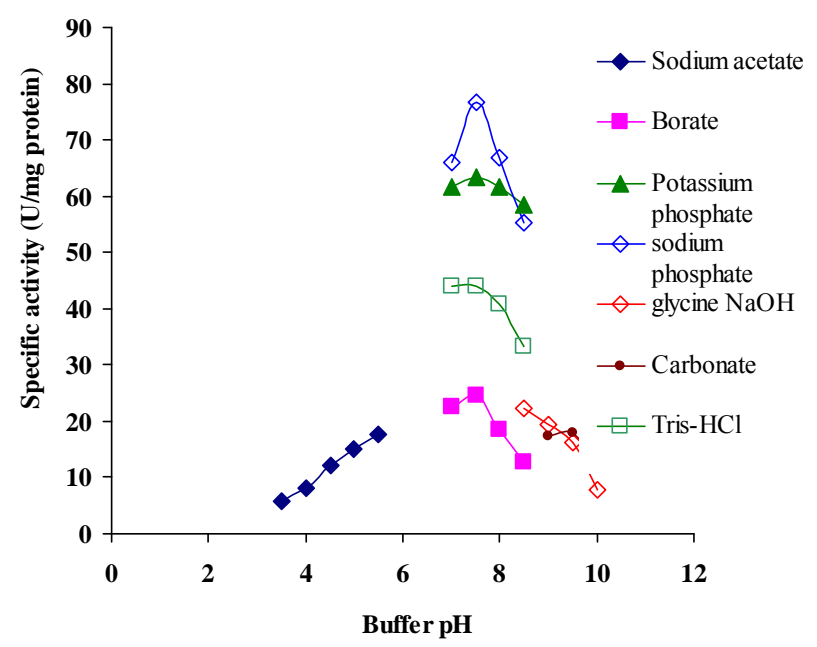

Figure 3. Optimization of buffer system.

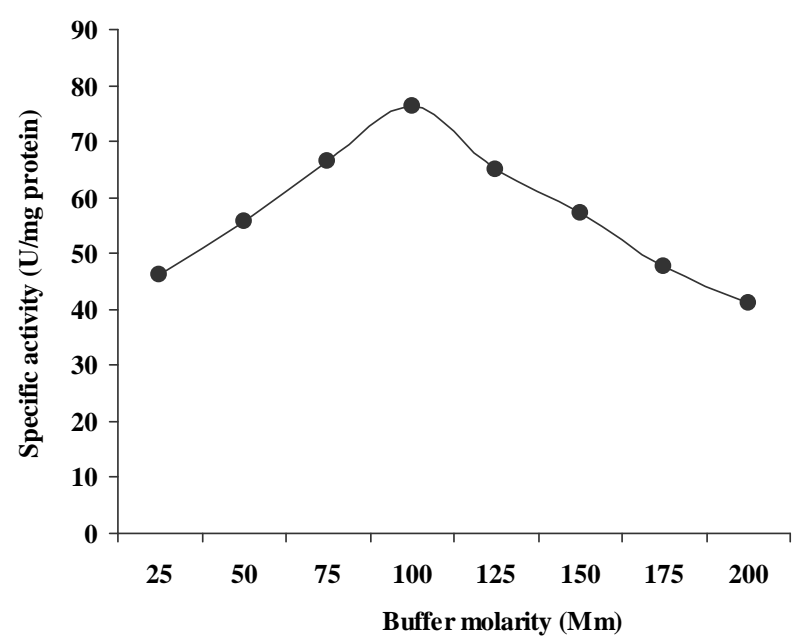

Figure 4. Effect of buffer molarity on xylanase activity.
[21] observed xylanase activity using sodium phosphate buffer (0.05 M, pH 7.0 from B. subtilis ASH. Khasin et al., [22] reported maximum enzyme activity at $50 \mathrm{mM}$ in Bacillus stearothermophilus T-6.

\subsubsection{Effect of Incubation Period}

Incubation period has a profound effect on enzyme activity. Specific duration of incubation is required for substrates to bind to the enzyme's active sites. Thus after a specific incubation period no increase in activity is observed because all the active sites of enzymes are blocked by the substrates. To learn the impact of incubation time on xylanase activity, reaction was terminated at a range of time intervals i.e. 1 minute to 30 minutes. The enzyme activity $(76.35 \mathrm{U} / \mathrm{mg})$ was found to be maximum within 5 minutes of incubation as shown in Figure 5. Similarly Sanghi et al., [21] have reported 5 minutes reaction duration for purified xylanase of Bacillus subtilis ASH, which is found in conformity with the present case. However, Yin et al., [23] in an earlier study observed 30 minutes optimum reaction time for xylanase of Bacillus sp. YJ6 which is towards higher side as reported in the present study.

\subsubsection{Effect of Reaction Temperature on Xylanase Activity}

To determine the effect of reaction temperature on xylanase activity, the reaction was performed at different temperatures ranging from $40^{\circ} \mathrm{C}$ to $75^{\circ} \mathrm{C}$. The optimum temperature for xylanase activity was found to be $60^{\circ} \mathrm{C}$ as shown in Figure 6. The results are in close agreement with that obtained by Ghesse and Gashe, [24] where the $\mathrm{pH}$ optimum was $60^{\circ} \mathrm{C}$. Xylanase exhibited quite good activity at the temperature ranging from $30^{\circ} \mathrm{C}$ to $60^{\circ} \mathrm{C}$, with optimum activity at $40^{\circ} \mathrm{C}$ and retained about $80 \%$ activity at $60^{\circ} \mathrm{C}$ [18]. Xylanase activity at different temperatures showed the activity increase up to $55^{\circ} \mathrm{C}$ and then declined progressively retaining $57 \%$ of the activity at $65^{\circ} \mathrm{C}$.

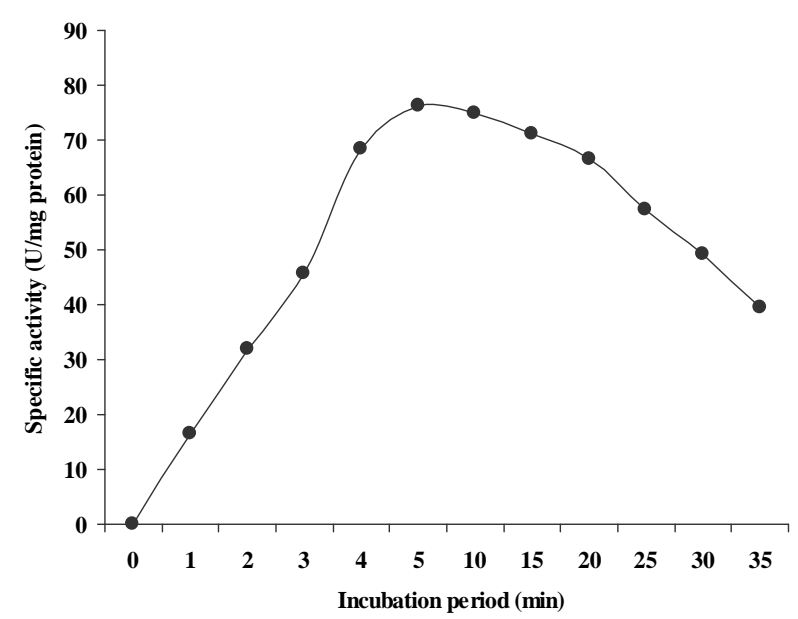

Figure 5. Incubation period for enzyme reaction. 


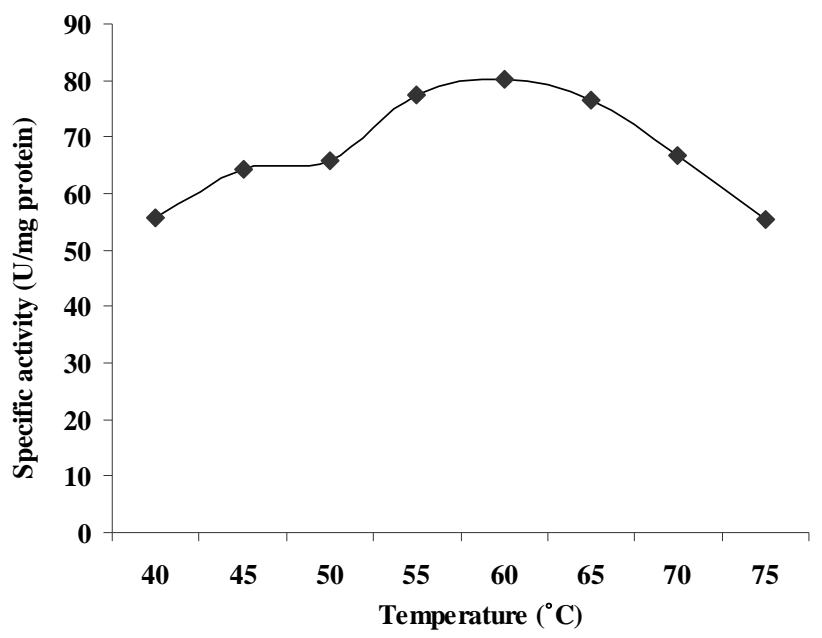

Figure 6. Effect of reaction temperature on xylanase activity.

The optimum temperature of the purified xylanase from B. subtilis was $55^{\circ} \mathrm{C}$ as the enzyme was most active at this temperature [21]. The results of current work are also in close conformity to the findings of Kavita et al., [25] they reported that the purified xylanase from the fungus Aspergillus nidulans KK-99 exhibited highest activity at $55^{\circ} \mathrm{C}$.

\subsubsection{Effect of Substrate Concentration}

The enzyme reaction was carried out at different concentrations of xylan in the reaction mixture ranging from $0.25 \%$ to $2.0 \%$ amd maximum activity was recorded in the presence of $1.0 \%$ of xylan (Figure 7). Similar results have been reported by Muthezhilan et al., [26] and Sanghi et al. [21].

\subsubsection{Effect of Enzyme Concentration}

The enzyme reaction was carried out at different concentrations of supernatant in the reaction mixture ranging from $5 \mu \mathrm{g} / \mathrm{ml}$ to $30 \mu \mathrm{g} / \mathrm{ml}$ and maximum activity was recorded in the presence of $25 \mu \mathrm{g} / \mathrm{ml}$ of enzyme (Figure 8). A decrease in activity was observed on increasing the concentration beyond $25 \mu \mathrm{g} / \mathrm{ml}$, which is in accordance to Sanghi et al., [21] (0.02 $\mathrm{ml}$ of appropriately diluted enzyme extract).

\subsubsection{Effect of Metal Ions}

The effect of metal ions on xylanase activity was studied and the results are summarized in Figure 9. All the metal ions used at $1 \mathrm{mM}$ concentration had inhibited xylanase activity. After addition of $1 \mathrm{mM}$ of $\mathrm{CuSO}_{4} \cdot 5 \mathrm{H}_{2} \mathrm{O}$, $\mathrm{CdCl}_{3} \cdot 2 \mathrm{H}_{2} \mathrm{O}, \mathrm{ZnSO}_{4} \cdot 7 \mathrm{H}_{2} \mathrm{O}$ and $\mathrm{CaCl}_{2} \cdot 2 \mathrm{H}_{2} \mathrm{O}$, a drastic decrease in xylanase activity was observed. Heavy metals like $\mathrm{Hg}^{2+}, \mathrm{Fe}^{3+}, \mathrm{Cu}^{2+}, \mathrm{Cd}^{2+}$, and $\mathrm{Zn}^{2+}$ strongly inhibited xylanase activity and presence of $\mathrm{Mn}^{2+}$ has been reported to inhibit xylanase activity of Bacillus sp. strain K-1 and Bacillus halodurans S7, respectively [18].

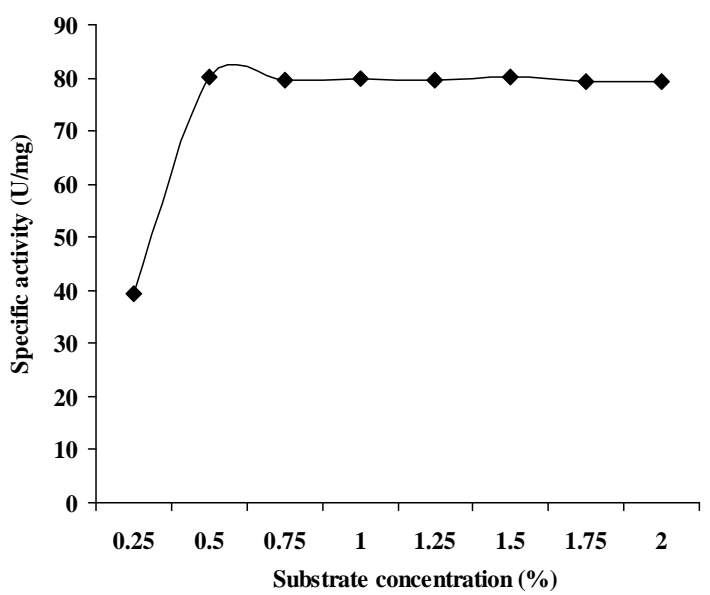

Figure 7. Effect of xylan concentration on xylanase activity.

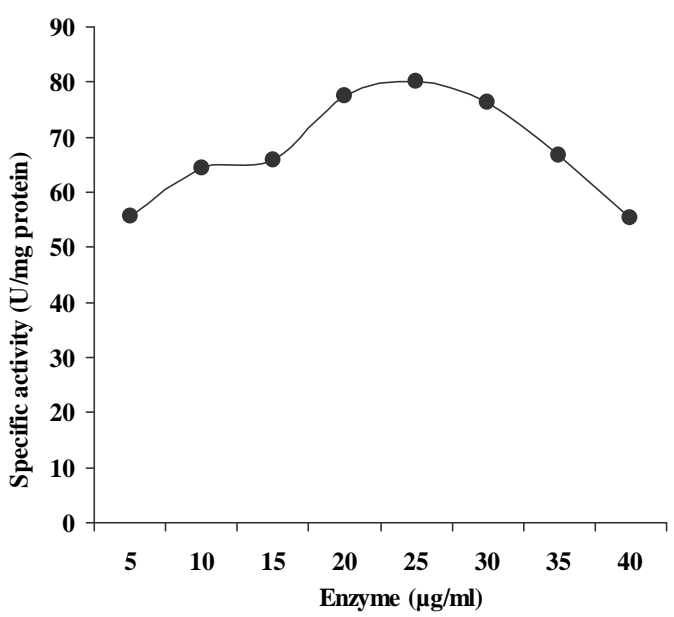

Figure 8. Effect of enzyme concentration on xylanase activity.

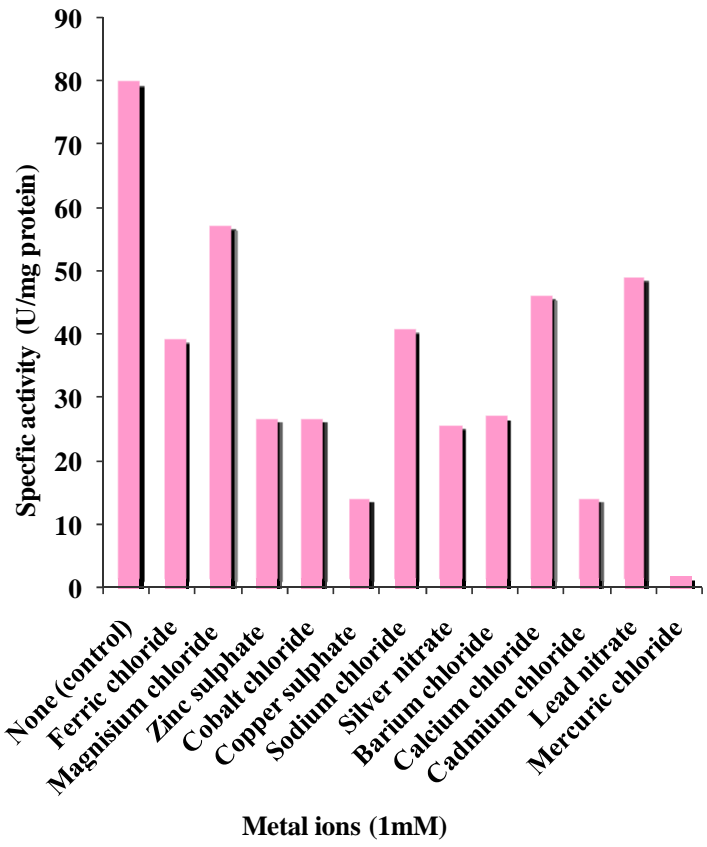

Figure 9. Effect of metal ions on xylanase activity. 
Xylanase activity was strongly inhibited by $\mathrm{Hg}^{2+}$ which might be due to its interaction with sulfhydryl groups present on the enzyme. $\mathrm{Cu}^{2+}$ ions were also found to be inhibitory causing $30 \%$ inhibition of enzyme activity. Some other metal ions like $\mathrm{Na}^{2+}, \mathrm{K}^{+}, \mathrm{Ca}^{2+}, \mathrm{Ni}^{2+}$ and $\mathrm{Zn}^{2+}$ decreased the enzyme activity [21].

\subsubsection{Thermostability of Xylanase}

Thermal stability is an interesting enzymes property due to the great industrial importance. The enzyme was preincubated at different temperatures and its activity was assayed after every 60 minutes till 300 minutes. The enzyme was fairly stable at $25^{\circ} \mathrm{C}$ and $45^{\circ} \mathrm{C}$ for upto 120 minutes. As the temperature was increased, the xylanase activity decreased considerably. A sharp decrease in activity was observed when the enzyme was preincubated at $105^{\circ} \mathrm{C}$; the activity was almost nil after 180 minutes (Figure 10). Shah and Madamwar, [27] found that the xylanase retained $100 \%$ activity at $30^{\circ} \mathrm{C}$ after 3 hours while at $40^{\circ} \mathrm{C}$ only marginal decrease was found. The enzyme was sensitive to $50^{\circ} \mathrm{C}$, retaining $71 \%$ after 30 minutes exposure and only $30 \%$ activity after 3.0 hours. Thermostability of the purified xylanase from Bacillus subtilis was studied by Sanghi et al., [21] at different temperatures $\left(30^{\circ} \mathrm{C}-60^{\circ} \mathrm{C}\right)$ for $10 \mathrm{~min}$ at $\mathrm{pH} 7.0$, quickly chilled and assayed for its residual activity at $55^{\circ} \mathrm{C}$ revealing no loss of activity up to $45^{\circ} \mathrm{C}$. However, it retained $80 \%$ and $51 \%$ of its activity after preincubation at $55^{\circ} \mathrm{C}$ and $60^{\circ} \mathrm{C}$ respectively. Significant enzyme stability at higher temperatures would be important for its industrial application. Purified xylanases exhibiting optimum temperature in the range of $50^{\circ} \mathrm{C}-55^{\circ} \mathrm{C}$ have been reported from several Bacillus and Streptomyces sp. [28,29].

\subsubsection{Time Course of Enzyme Reaction at Different Temperatures}

Xylanase reactions were followed upto 180 minutes at different temperatures $\left(35^{\circ} \mathrm{C}-65^{\circ} \mathrm{C}\right)$. The results obtained have been shown in Figure 11. Sugar estimation was done after different time intervals viz. 5, 10, 30, 60, 120, 180 minutes. Maximum enzyme activity was observed at $55^{\circ} \mathrm{C}$ after 5 minutes of reaction. After 60 minutes, the enzyme activity at all the temperatures remained almost constant. This may be due to the fact that all the catalytic sites of the enzyme have been blocked by the substrate and no more sites are there for substrate to act upon.

\subsubsection{Shelf Life of Enzyme}

Shelf life of xylanase of Pseudomonas sp. XPB-6 was studied at both room temperature and at $4^{\circ} \mathrm{C}$. The results obtained are shown in Figure 12. The enzyme was stable both at room temperature and at $4^{\circ} \mathrm{C}$ for 90 and 28 days respectively. The enzyme retained almost $50 \%$ activity at room temperature after 40 days. Similar results were

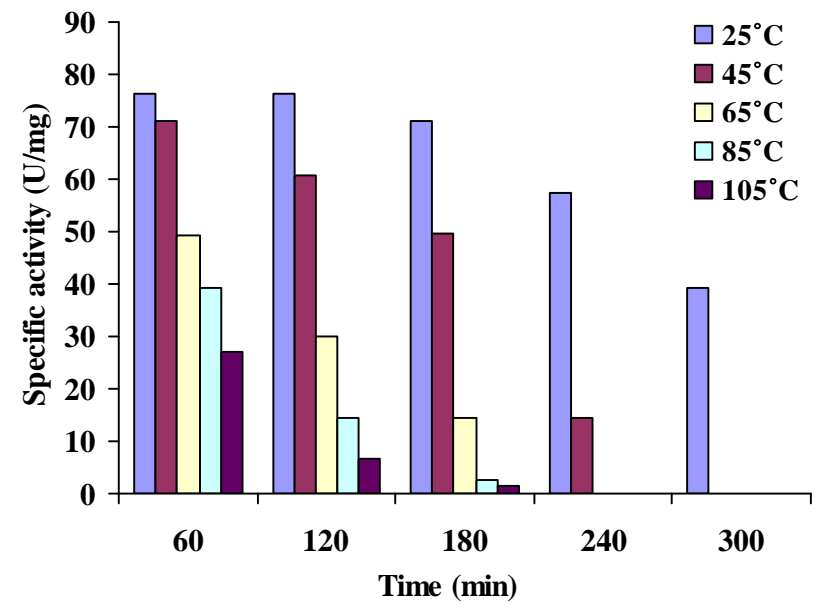

Figure 10. Thermostability of xylanase.

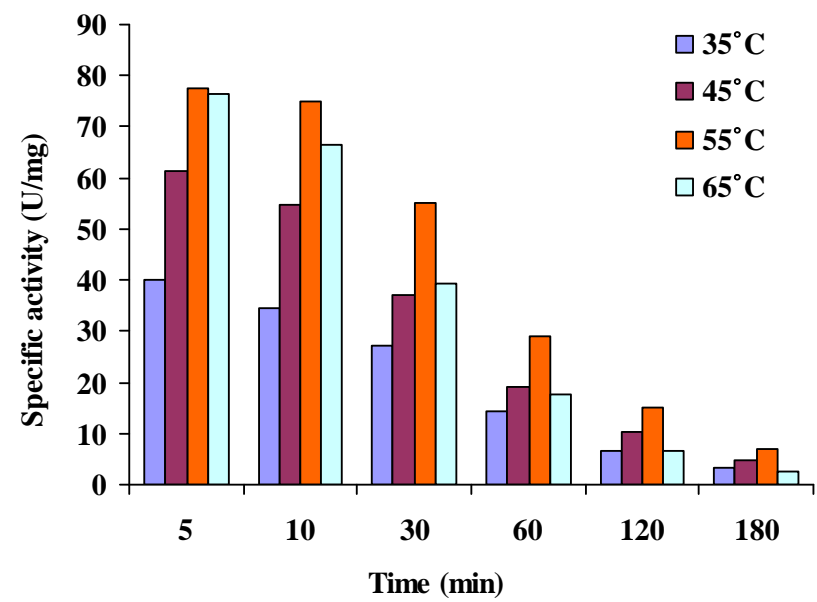

Figure 11. Time course of enzyme reaction.

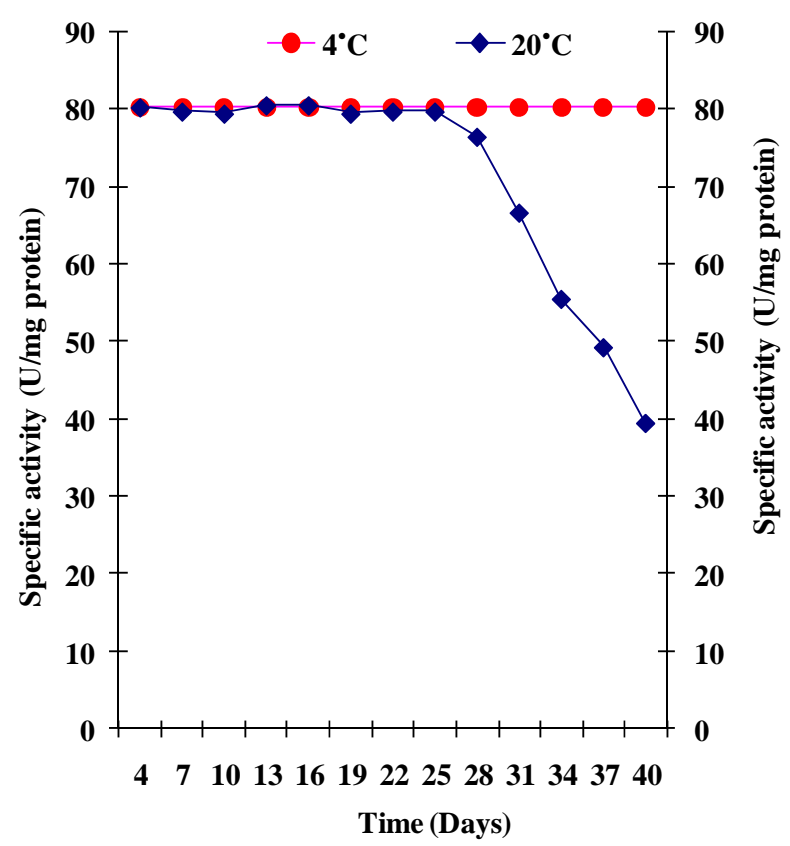

Figure 12. Shelf life of enzyme. 
obtained by Sanghi et al., [21] as purified enzyme did not lose any activity when stored at $4^{\circ} \mathrm{C}$ for six weeks but thereafter, a decline was observed. The enzyme retained $80 \%$ its initial activity after 10 weeks. On the other hand, at room temperature, the enzyme was completely stable for three weeks but showed $60 \%$ and $5 \%$ residual activity after storage for 7 and 10 weeks, respectively. Xylanase from Bacillus subtilis which showed maximum activity at $60^{\circ} \mathrm{C}$, did not lose its activity at $\mathrm{pH} 8.2$ upto one year at $4^{\circ} \mathrm{C}$ to $25^{\circ} \mathrm{C}$ but was inactivated when froze [30]. Shah and Madamwar, [27] observed full enzyme activity when stored in deep freeze up to 6 months. At refrigeration temperature, no loss of activity was found up to 2 weeks but after 4 weeks a marginal decrease $(5 \%-10 \%)$ was found. At room temperature decrease in activity was not found for up to 2 days but at the end of a week $10 \%$ loss in enzyme activity was found.

\subsubsection{Determination of $K_{\mathrm{m}}$ and $V_{\max }$ of Purified Xylanase from Pseudomonas sp. XPB-6}

The purified xylanase of Pseudomonas sp. XPB-6 had $V_{\max }$ of $144.92 \mathrm{IU} / \mathrm{mg}$ protein and the $K_{\mathrm{m}}$ values were $0.60 \mathrm{mg} / \mathrm{ml}$ respectively, as determined by Line Weaver Burk plot using Birchwood xylan as substrate (Figure 13).

Earlier reports revealed that xylanase enzyme of $A$. fischeri Fxnl had a $K_{\mathrm{m}}$ of $4.88 \mathrm{mg} / \mathrm{ml}$ and $V_{\max }$ of 588 $\mathrm{mmol} / \mathrm{min} / \mathrm{mg}$ [31]. Two types of xylanases were produced by thermotolerant Aspergillus FP-470 strain; $K_{\mathrm{m}}$ values were 0.171 and $0.177 \mathrm{mg}$ xylan/ml and $V_{\max }$ were $1.96 \times 10^{-2}$ and $0.986 \mathrm{mmol} / \mathrm{min} / \mathrm{mg}$, respectively [32]. The purified enzyme from $A$. ochraceus had a $K_{\mathrm{m}}$ and $V_{\max }$ values were $1 \times 10^{3} \mathrm{M}$ and $19.6 \mathrm{mmol} / \mathrm{min} / \mathrm{mg}$, respectively [33]. Angayarkanni et al., [34] observed the Aspergillus sp. xylanases had $V_{\max }$ of 313.56 to 450.20 $\mathrm{IU} / \mathrm{mg}$ protein, $K_{\mathrm{m}}$ of 0.80 to $2.50 \mathrm{mg} / \mathrm{ml}$. Menon et al.,

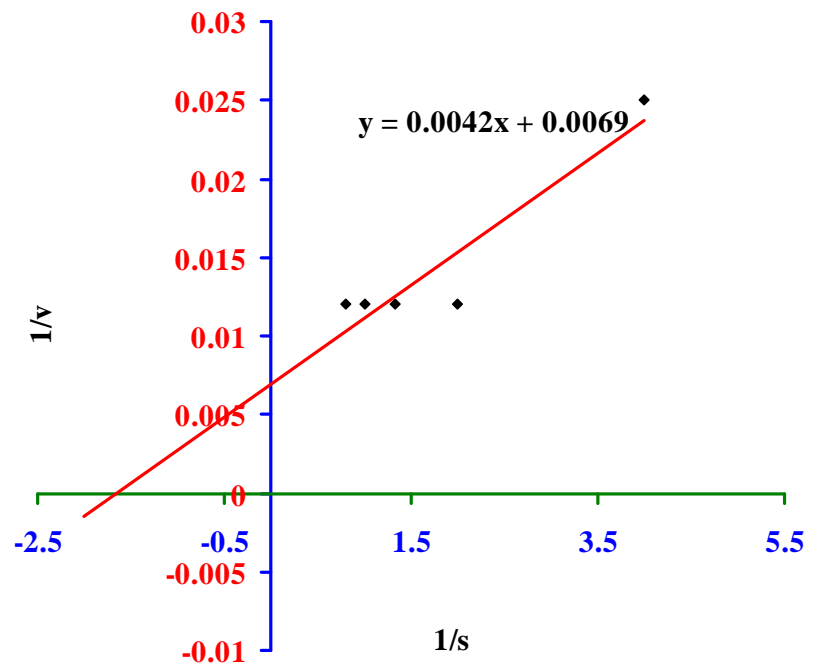

Figure 13. Determination of $K_{\mathrm{m}}$ and $V_{\max }$.
[18] observed $\mathrm{K}_{\mathrm{m}}$ and $V_{\max }$ values for Bacillus sp. by Lineweaver Burk double reciprocal plot. The substrate, Birchwood xylan gave $K_{\mathrm{m}}$ value $5.3 \mathrm{mg} / \mathrm{ml}$ and the $V_{\max }$ $0.42 \mu \mathrm{mol} / \mathrm{min} / \mathrm{ml}(6593.4 \mu \mathrm{mol} / \mathrm{min} / \mathrm{mg}$ protein), Birchwood xylan gave $K_{\mathrm{m}}$ value $5.3 \mathrm{mg} / \mathrm{ml}$ and the $V_{\max }$ $0.42 \mu \mathrm{mol} / \mathrm{min} / \mathrm{ml}(6593.4 \mu \mathrm{mol} / \mathrm{min} / \mathrm{mg}$ protein $)$.

\section{REFERENCES}

[1] M. A. Correia, K. Mazumder, J. L. Brás, S. J. Firbank, Y. Zhu, R. J. Lewis, W. S. York, C. M. Fontes and H. J. Gilbert, "Structure and Function of an Arabinoxylan-Specific Xylanase," The Journal of Biological Chemistry, Vol. 286, No. 25, 2011, pp. 22510-22520. doi:10.1074/jbc.M110.217315

[2] M. S. Butt, M. T. Nadeem, Z. Ahmad and M. T. Sultan, "Xylanases in Baking Industry," Food Technology and Biotechnology, Vol. 46, No. 1, 2008, pp. 22-31.

[3] K. K. Wong, L. U. Tan and J. N. Saddler, "Multiplicity of $\beta$-1,4-Xylanase in Microorganisms: Functions and Applications," Microbiology Reviews, Vol. 52, No. 3, 1988, pp. 305-317.

[4] K. Poutanen, M. Tenkanen, H. Korte and J. Puls, "Accessory Enzymes Involved in the Hydrolysis of Xylans," In: G. F. Leatham and M. E. Himmel, Eds., Enzymes in Biomass Conversion, American Chemical Society, Washington DC, 1991, pp. 426-433.

[5] M. A. A. Al-Bari, M. M. S. Rahman, M. A. U. Islam, M. E. Flores and M. S. A. Bhuiyan, "Purification and Characterization of a $\beta$-(1,4)-Endoxylanase of Streptomyces bangladeshiensis sp.," Research Journal of Cell and Molecular Biology, Vol. 1, No. 1, 2007, pp. 31-36.

[6] M. K. Bhatt, "Cellulases and Related Enzymes in Biotechnology," Biotechnology Adventures, Vol. 18, No. 5, 2000, pp. 355-383. doi:10.1016/S0734-9750(00)00041-0

[7] Q. K. Beg, M. Kapoor, L. Mahajan and G. S. Hoondal, "Microbial Xylanases and Their Industrial Applications: A Review," Applied Microbiology and Biotechnology, Vol. 56, No. 3-4, 2001, pp. 326-338. doi: $10.1007 / \mathrm{s} 002530100704$

[8] S. Ninawe and R. C. Kuhad, "Bleaching of Wheat StrawRich Soda Pulp with Xylanase from a Thermoalkalophilic Streptomyces cyaneus SN 32," Bioresource Technology, Vol. 97, No. 18, 2006, pp. 2291-2295. doi:10.1016/j.biortech.2005.10.035

[9] R. C. Kuhad, M. Kapoor and K. Chaudhary, "Production of Xylanases from Streptomyces sp. M-83 Using Cost Effective Substrates and Its Application in Improving Digestibility of Monogastric Animal Feed," Industrial Journal of Microbiology, Vol. 46, No. 2, 2006, pp. 109-119.

[10] M. L. T. Polizeli, A. C. S. Rizzatti, R. Monti, H. F. Terenzi, J. S. Jorge and D. S. Amorim, "Xylanases from Fungi: Properties and Industrial Applications," Applied Microbiology and Biotechnology, Vol. 67, No. 5, 2005, pp. 577-591. doi:10.1007/s00253-005-1904-7

[11] J. L. Miller, "Use of Dinitrosalicylic Acid Reagent for Determination of Reducing Sugar," Analytical Biochemistry, Vol. 31, No. 3, 1959, pp. 426-428. 
doi:10.1021/ac60147a030

[12] R. K. Scopes, In: C. R. Cantor, Ed., Protein Purification, Springer-Verlag, New York, 1982, pp. 125-131.

[13] E. C. Carmona, M. R. Brochetto-Braga, A. A. PizziraniKleiner and J. A. Jorge, "Purification and Biochemical Characterization of an Endoxylanase from Aspergillus versicolor," FEMS Microbiology Letters, Vol. 166, No. 2, 1998, pp. 311-315. doi:10.1111/j.1574-6968.1998.tb13906.x

[14] M. M. Bradford, "A Rapid and Sensitive Method for the Quantitation of Microgram Quantities of Protein Utilizing the Principle of Protein-Dye Binding," Analytical Biochemistry, Vol. 72, No. 1-2, 1976, pp. 248-254. doi:10.1016/0003-2697(76)90527-3

[15] U. K. Laemmli, "Cleavage of Structural Proteins during the Assembly of the Head of Bacteriophage T4," Nature, Vol. 227, 1970, pp. 3397-3407. doi:10.1038/227680a0

[16] P. J. Blackshear, "System for Poly Acrylamide Gel Electrophoresis," Methods in Enzymology, Vol. 104, 1984, pp. 237-255. doi:10.1016/S0076-6879(84)04093-3

[17] D. M. Bollag and S. J. Edelstein, "Protein Concentration Determination," In: D. M. Bollag and S. J. Edelstein, Eds., Protein Methods, Wiley-Liss, New York, 1991.

[18] G. Menon, K. Mody, J. Keshri and B. Jha, "Isolation, Purification, and Characterization of Haloalkaline Xylanase from a Marine Bacillus pumilus Strain, GESF-1," Biotechnology and Bioprocess Engineering, Vol. 15, No. 6, 2010, pp. 998-1005. doi:10.1007/s12257-010-0116-x

[19] W. Shao, S. Deblois and J. Wiegel, "A High-MolecularWeight, Cell-Associated Xylanase Isolated from Exponentially Growing Thermoanaerobacterium sp. Strain JW/SL-YS485," Applied Environmental Microbiology, Vol. 61, No. 3, 1995, pp. 937-940.

[20] A. Dhillon and S. Khanna, "Production of a Thermostable Alkalitolerant Xylanase from Bacillus circulans AB16 Grown on Wheat Straw," World Journal of Microbiology and Biotechnology, Vol. 27, No. 4, 2000, pp. 325-327. doi:10.1023/A:1008911026606

[21] A. Sanghi, N. Garg, V. K. Gupta, A. K. Mittal and R. C. Kuhad, "One-Step Purification and Characterization of Cellulase-Free Xylanase Produced by Alkalophilic Bacillus subtilis ASH," Brazilian Journal of Microbiology, Vol. 4, No. 2, 2010, pp. 467-476. doi:10.1590/S1517-83822010000200029

[22] A. Khasin, I. Alchanati and Y. Shoham, "Purification and Characterization of a Thermostable Xylanase from Bacillus stearothermophilus T-6," Applied Microbiology and Biotechnology, Vol. 59, No. 6, 1993, pp. 1725-1730.

[23] L. J. Yin, H. H. Lin, Y. I. Chiang and S. Jiang, "Bioproperties and purification of xylanase from Bacillus sp. YJ6," Journal of Agricultural Food Chemistry, Vol. 58, No. 1, 2010, pp. 557-562. doi:10.1021/jf902777r
[24] A. Ghesse and B. A. Gashe, "Production of Alkaline Xylanase by an Alkaliphilic Bacillus sp. Isolated from an Alkaline Soda Lake," Journaj of Applied Microbiology, Vol. 83, No. 4, 1997, pp. 402-406.

[25] T. Kavita, S. Gupta and R. C. Kuhad, "Properties and Application of a Partially Purified Alkaline Xylanase from an Alkalophilic Fungus Aspergillus nidulans KK-99," Bioresource Technology, Vol. 85, No. 1, 2002, pp. 39-42. doi:10.1016/S0960-8524(02)00064-0

[26] R. Muthezilan, R. Ashok and S. Jayalakshmi, "Production and Optimization of Thermostable Alkaline Xylanase by Penicillium oxalicum in Solid State Fermentation," African Journal of Microbioogyl Research, 2007, pp. 20-28.

[27] A. R. Shah and D. Madamwar, "Xylanase Production by a Newly Isolated Aspergillus foetidus Strain and Its Characterization," Process Biochemistry, Vol. 40, No. 5, 2005, pp. 1763-1771. doi:10.1016/j.procbio.2004.06.041

[28] A. Archana and T. Satyanarayana, "Purification and Characterization of a Cellulase-Free Xylanase of a Moderate Thermophile Bacillus licheniformis A99," World Journal of Microbiology and Biotechnology, Vol. 19, No. 1, 2003, pp. 53-57. doi:10.1023/A:1022527702400

[29] K. Virupakshi, K. L. Kyu and M. Tanticharoen, "Purification and Properties of a Xylan-Binding Endoxylanase from Alkaliphilic Bacillus sp. Strain K-1," Applied Environmental Microbiology, Vol. 65, No. 2, 2005, pp. 694697.

[30] P. Sa-Pereira, A. Mesquita, J. C. Durate, M. A. Barros and M. Costa-Ferreira, "Rapid Production of Thermostable Cellulose-Free Xylanase by a Strain of Bacillus subtilis and Its Properties," Enzyme Microbial Technology, Vol. 30, No. 7, 2002, pp. 924-933. doi:10.1016/S0141-0229(02)00034-0

[31] K. ChandraRaj and T. S. Chandraz, "Production of Cellulase-Poor Xylanase by a Newly Isolated Fungus Fxn1," In: R. S. Kahlon, Ed., Perspectives in Microbiology, National Agriculture Technology Information Centre, 1996, pp. 269270.

[32] L. P. M. Castro, B. A. Trejo-Aguilar and G. A. Osorio, "Thermostable Xylanases Produced at $37^{\circ} \mathrm{C}$ and $45^{\circ} \mathrm{C}$ by a Thermotolerant Aspergillus Strain," FEMS Microbiology Letters, Vol. 146, No. 1, 1997, pp. 97-102.

[33] S. R. Biswas, S. C. Jana, A. K. Mishra and G. Nanda, "Production, Purification and Characterization of Xylanase from a Hyperxylanolytic Mutant of Aspergillus ochraceus," Biotechnology and Bioengineering, Vol. 35, No. 3, 1990, pp. 244-251. doi:10.1002/bit.260350305

[34] J. Angayarkanni, M. Palaniswamy, B. V. Pradeep and K. Swaminathan, "Biochemical Substitution of Fungal Xylanases for Prebleaching of Hardwood Kraft Pulp," African Journal of Biotechnology, Vol. 5, No. 10, 2006, pp. 921-929. 